\title{
A New Management Model for Higher Education in Dubai-UAE: Quality Management in Alignment with Professional Autonomy
}

\author{
Iman Rabah ${ }^{1}$ \\ ${ }^{1}$ Management, Leadership, Policy, Dubai, United Arab Emirates \\ Correspondence: Iman Rabah, Management, Leadership, Policy, Dubai, United Arab Emirates. E-mail: \\ imanbf1@hotmail.com
}

Received: November 1, 2016

Accepted: November 9, 2016

Online Published: January 21, 2017

doi:10.5539/res.v9n1p165

URL: http://dx.doi.org/10.5539/res.v9n1p165

\begin{abstract}
The purpose of this paper is to develop a model of Total Quality Management (TQM) that does not damage the scholarly values of higher education and which enhances professional autonomy, including academic freedom and academic quality in teaching and research. The theoretical framework includes an interpretive study that examines the functional, structural, and cultural aspects of implementing TQM concepts in higher education and the concepts that should be modified.

The paper follows the qualitative approach based on the interpretive epistemological paradigm. This research uses empirical data on higher education quality management practices in their natural setting through an interpretive study. The logic of inquiry adopts inductive reasoning that constructs or evaluates general propositions that are derived from specific examples. Empirical data is collected from faculty members from a sample of two universities, including one public university and one private university in Dubai, the United Arab Emirates (UAE), in order to study academics' perceptions of TQM in higher education. The methodology involves document analysis and collecting interpretations and narratives in order to study the positive and negative influences of quality management practices on, academics, research and the teaching process. The methodology also includes quantitative analysis using the survey instrument for the sake of triangulation.

The designed management model which is the result of this paper takes into consideration the issues caused by TQM as a form of new public management, including overload in teaching, administrative tasks, faculty turnover and the reasons behind this along with the quality of teaching and research. Inapplicable TQM concepts are modified based on traditional university management models in order to fit the higher educational context, taking into account higher education leadership and the cross-cultural context that universities operate in especially in Dubai.
\end{abstract}

Keywords: higher education, TQM, professional autonomy, leadership, collegiality, Dubai

\section{Introduction}

The concept of quality is an old one and can be traced back by historians to Ancient China and more specifically the Western Zhou Dynasty in the eleventh century B.C. as a control system for handicraft production (Juran, 1995, p. 3). One of the organizational management methods that were developed in the modern period, in the late 19th century in industry, was quality control through the detection of defects in manufacturing products in order to take corrective action, and this was expanded into quality assurance in the course of preventing errors before they occur (Evans \& Lindsay, 2005). After that, Total Quality Management (TQM) came into prominence in the 1980s and 1990s as a response to some of the problems that arose from using mechanical ways of managing in some organizations which had led to limitations in human capacities' development and personal growth (Morgan, 2006). TQM is a management system that was initiated in Japan by the American management scholar Edward Deming (2000) in the 1980s, which focuses on customers, leadership, teamwork, empowerment, corporate culture, strategic objectives, and continuous improvement. As Antony and Preece (2002) explain, TQM started in manufacturing in Japan and was gradually proliferated to the service industry and then to the public sector areas with the New Public Management like education and healthcare in developed and developing countries. 
In the 1980s and 1990s the expansion of university systems to accommodate a larger percentage of the population going to university and the increase in technology expenses accompanied with the financial constrictions and the confused relationship between universities and governments all reduced the self-confidence of the academic profession in its dedication to its calling (Shils, 1997, p. 7). Those changes had a great impact on the management systems in the universities, thus leading to the erosion of the collegial model including shared governance, academic freedom, professional autonomy, and academic tenure. Suddenly, new management concepts emerged like productivity, revenues, employment flexibility, moderate evaluation of students, pedagogical issues and many others (Rochford, 2003).

The theoretical framework includes an interpretive study that examines the functional, structural, and cultural aspects of implementing TQM concepts in higher education and the concepts that should be modified. Inapplicable TQM concepts are modified based on traditional university management models in order to fit the higher educational context, taking into account higher education leadership and the cross-cultural context that universities operate in especially in Dubai.

\section{Empirical Study}

The results of the empirical study of the two universities are presented for a grounded theory, which leads to the construction of a modified quality management model for higher education. These results are presented by using the document analysis followed by the survey results and the results of the interviews. Since this study is emergent, the process of inquiry, supporting arguments, and questions of interest were developed as the research progresses. Since the paper is based on social constructivism combined with interpretivism, general and broad questions were asked in order to help participants construct the meaning of their situation. The qualitative methods were document analysis and semi-structured interviews along with part of the survey questionnaire. The quantitative methods included a section of the questionnaire that collected quantitative data and thus helped in quantitative analysis. Based on the emergent study approach, these tasks were conducted in this order: first, the majority of the documents analysis was done in order to determine what kinds of quality management are being used in the studied universities, and this required a modification in the survey instrument. The survey is conducted next since the recruitment of most faculty interviewees was done through this instrument. Finally, the interview guides were finalised based on feedback from the two preceding instruments. Semi-structured interviews were conducted with some faculty members based on criterion sampling.

\subsection{Documents Analysis}

The analysed documents include: academic policies in the two universities under study, and general documents of management in universities like the standards for licensure and accreditation of the Commission for Academic Accreditation (CAA) in the UAE and the UNESCO international covenant on academic freedom. Those documents were analysed and used in modifying the TQM inapplicable characteristics to higher education in the new model of this paper.

\subsubsection{University Documents}

The relevant policies examined here include those related to faculty workload, faculty promotion, research strategies and committees, faculty committees, faculty evaluation, planning policies, peer review policies, and library committees, etc. The purpose of critically analyzing those documents is to check all faculty management related matters to quality management concepts.

In the private university, in order to be promoted and according to the promotion policy, faculty members are expected to perform at increasingly higher levels as they advance in their careers. This can be recognized by: a higher quality of performance and recognition in teaching and learning, a greater contribution to the advancement of the research and scholarship of their discipline, and an increase in the complexity and responsibility of their duties and service to the university. In the public university, the promotion policy is very similar to that detailed above and academic staff should be recruited and rewarded according to the disciplines of research, teaching and administration.

The two universities have very similar policies when it comes to how faculty members' responsibilities are distributed among teaching, research, administration, leadership, and community service. The policies of the two universities assign the largest responsibility of faculty members to teaching, yet the policies state that this may be modified for many reasons. What the actual workloads are cannot be known based on policy analysis only. This information is obtained in the survey and interview results below.

While the private university does not include the term "academic freedom" in any of its policies, in its "Role and Responsibility of Academic Staff" policy the public university states that academic freedom is the right of 
members of the academic community to study, discuss, investigate, teach, conduct research and publish as appropriate to their respective roles, responsibilities, and disciplines.

In the private university and according to the continuous improvement policy, the process of continuous improvement is the responsibility of the Office of Institutional Effectiveness. Process improvement projects are carried out according to a continuous improvement process flowchart, which is based on quality management and on Deming's PDCA cycle as stated clearly in the policy. The effectiveness of this process for the academic department was also included for discussion in the interviews.

According to the subject-instructor evaluations process, the private university depends on students' evaluation of the instructor while the public university looks for peer observations, students' feedback forms, and self-evaluation. This evaluation process is discussed with faculty members in the interview instrument for further clarifications.

\subsubsection{Documents on University Management}

The analysis of the two universities' policies demonstrates that both have very similar policies in compliance with the standards of the Commission for Academic Accreditation (CAA) standards that they are accredited by. Higher education institutes seek accreditation from the Ministry of Higher Education as an obligatory requirement in order to be considered by the government in the country. Universities have different reasons for pursuing accreditation, as for some of them accreditation is inevitable while for others it is for the purpose of improving quality (Heriot, Franklin, \& Austin, 2009). The CAA is offered by the Ministry of Higher Education in the UAE to higher education undergraduate and postgraduate programs.

The CAA requires that a higher education institute has a specific mission presented in a mission statement. The institute's processes should be linked to its mission and also all actions, future planning, use of resources, and evolution should be guided by this mission (CAA, 2016). Strategic planning and implementation are dominant in CAA standards that are mission driven, and therefore faculty activities such as pedagogical approaches, curricula design, and research type should be aligned with the mission (CAA, 2016).

The UNESCO international covenant on academic freedom is also important in building the new model of this paper. It discusses the importance of academic freedom and autonomy in higher education including (UNESCO, 2015).

The above documents' analysis show that the private university applies some of the TQM concepts but the public university does not. Based on the emergent study approach, the information analyzed in these policies is integrated into the design of the survey and interview for further interpretation from faculty members.

\subsection{Survey}

The subjects of this paper are academic staff in both teaching and administrative positions. These include faculty members and senior administration deans, vice presidents, academics, and presidents. Sampling includes the whole faculty member population for a semi-structured survey instrument and purposive sampling for the interviewees' selection following the recommendation of Stake (1995) who argues that this is the best approach for this kind of study in order to serve its purpose. The questionnaire was sent to all faculty members by email, and the filled in questionnaires were returned by email. The in depth semi-structured interviews were all conducted with faculty members in their campus offices.

After obtaining the ethical approvals from the two universities, a participation information sheet was sent by email to all faculty members including faculty members with and faculty members without administrative positions. In addition, a consent form was attached to this first email along with the questionnaire.

After document analysis in the two universities there were many questions which needed to be asked to all faculty members in order to clarify some points and collect qualitative interpretations and quantitative data through a survey, as represented below. Some of those questions are analyzed quantitatively and others are analyzed qualitatively for the sake of triangulation. Overall, 56 questionnaires were sent to faculty members of the private university, 27 filled in questionnaire were returned. 22 questionnaires were sent to faculty members of the affiliated public university and 11 filled in questionnaires were returned. Therefore, the total number of questionnaires considered for this study is 38 questionnaires.

The first section of the questionnaire included demographic questions about gender and age, which aid in quantitative analysis and conducting inferential statistics and comparing responses between different groups. For example, although it may be considered that TQM practices would hinder faculty members from conducting research, there would be other reasons that do hinder them from research like professors who are mothers with 
heavy domestic responsibilities. Table 1 summarises the gender survey data, Table 2 summarises the current position survey data, and Table 3 summarises the marital status survey data of the questionnaire participants.

Table 1. Gender survey data

\begin{tabular}{ccccc}
\hline Gender & Distribution & $\begin{array}{c}\text { Average number of } \\
\text { publications per year }\end{array}$ & $\begin{array}{c}\text { Average satisfaction with } \\
\text { management practices }\end{array}$ & $\begin{array}{c}\text { Average satisfaction } \\
\text { with university policies }\end{array}$ \\
\hline Male & $55 \%$ & $2-3$ & satisfied & satisfied \\
Female & $45 \%$ & $1-2$ & dissatisfied & dissatisfied \\
Total & $100 \%$ & $1-2$ & $\begin{array}{c}50 \% \text { satisfied } / 50 \% \\
\text { dissatisfied (no mode) }\end{array}$ & satisfied \\
\hline
\end{tabular}

Table 2. Current position survey data

\begin{tabular}{ccccc}
\hline Current Position & Distribution & $\begin{array}{c}\text { Average number of } \\
\text { publications per year }\end{array}$ & $\begin{array}{c}\text { Average satisfaction level } \\
\text { with management practices }\end{array}$ & $\begin{array}{c}\text { Average satisfaction level } \\
\text { with university policies }\end{array}$ \\
\hline Full Professor & $16 \%$ & $2-3$ & Dissatisfied & Dissatisfied \\
Associate Professor & $29 \%$ & $2-3$ & Dissatisfied & Dissatisfied \\
Assistant Professor & $42 \%$ & $1-2$ & Satisfied & Satisfied \\
Adjunct Faculty & $5 \%$ & $1-2$ & Dissatisfied & Dissatisfied \\
Instructor & $8 \%$ & $2-3$ & Satisfied & Satisfied \\
Total & $100 \%$ & $1-2$ & dissatisfied (no mode) & satisfied \\
\hline
\end{tabular}

Table 3. Marital status survey data

\begin{tabular}{ccccc}
\hline Marital Status & Distribution & $\begin{array}{c}\text { Average number of } \\
\text { publications per year }\end{array}$ & $\begin{array}{c}\text { Average satisfaction with } \\
\text { management practices }\end{array}$ & $\begin{array}{c}\text { Average satisfaction } \\
\text { with university policies }\end{array}$ \\
\hline Married & $61 \%$ & $1-2$ & satisfied & Satisfied \\
Not married & $39 \%$ & $2-3$ & dissatisfied & Satisfied \\
Total & $100 \%$ & $1-2$ & $\begin{array}{c}50 \% \text { satisfied } / 50 \% \\
\text { dissatisfied (no mode) }\end{array}$ & satisfied \\
\hline
\end{tabular}

Based on eye balling of the quantitative survey data and analysis of the qualitative information collected from the questionnaire, the following five hypotheses were generated to be quantitatively tested using the statistics software SPSS.

Hypothesis 1: there is a significant difference between faculty members' gender and the average number of their publications per year. The average number of publications for the faculty who responded to the questionnaire is approximately two publications per year (S.D. $=0.72$, Mean=1.97, N=38). Female professors have fewer on average (S.D. $=0.68$, Mean=1.81, N=17) than male professors (S.D. $=0.73$, Mean=2.18, N=21). To study whether the difference is significant and since there are two experimental conditions and different subjects in each condition (males and females), the T-test (unrelated) was used. The results show that there is no significant difference between faculty members' gender and the number of their publications $(t=-1.6, d f=36, p=0.12)$ and therefore the hypothesis is rejected.

Hypothesis 2: there is a significant difference between marital status of faculty members and the average number of publications per year. The average number of publications for the faculty who responded to the questionnaire is approximately two publications per year (S.D. $=0.72$, Mean=1.97, N=38). Married professors have fewer on average (S.D. $=0.67$, Mean=1.78, N=23) than professors who are not married (S.D.=0.7, Mean=2.27, N=15). To study whether the difference is significant and since there are two experimental conditions and different subjects in each condition (married and not married-includes single/divorced/others), then T-test (unrelated) was used. The results show that there is a significant difference between marital status and the number of their publications $(\mathrm{t}=-2.132, \mathrm{df}=36, \mathrm{p}<0.05)$, and therefore the hypothesis is accepted. 
Hypothesis 3: there is a significant negative correlation between the number of children for faculty members and number of publications per year. Since data is nonparametric, spearman rho is used to study correlation significance. The results show that there is a significant correlation between the number of children for faculty members and number of publications ( $\mathrm{Rho}=-0.561, \mathrm{~N}=38, \mathrm{P}<0.01$ ). By constructing a scatter diagram using the number of children as the independent variable and the average number of publications per year as the dependent variable, this significant correlation is found to be negative, as presented in Figure 1: Hypothesis. Therefore, the hypothesis is accepted.

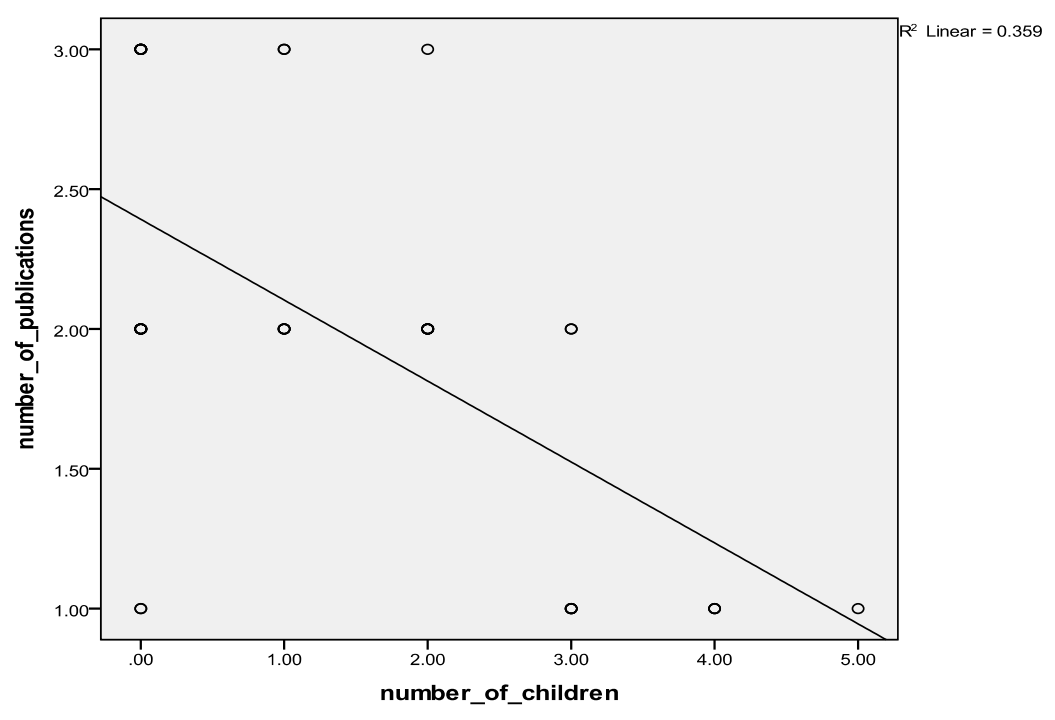

Figure 1. Hypothesis 3 scatter diagram

Hypothesis 4: there is a significant difference between faculty members' current positions and their satisfaction levels with the management practices related to teaching and research. The average satisfaction level of Full Professors is (S.D. $=0$, Mode $=$ dissatisfied, $\mathrm{N}=6$ ), the average satisfaction level of Associate professors is ( $\mathrm{S} . \mathrm{D} .=0$, Mode $=$ dissatisfied, $\mathrm{N}=11$ ), the average satisfaction level of Assistant professors is $(\mathrm{S} . \mathrm{D} .=0$, Mode $=\mathrm{satisfied}$, $\mathrm{N}=16$ ), the average satisfaction level of Adjunct Faculty members is (S.D. $=0$, Mode=dissatisfied, $\mathrm{N}=2$ ), and the average satisfaction level of instructors is $($ S.D. $=0$, Mode $=$ satisfied, N=3). Since the two variables are nominal, the chi-square test was done. The results show that there is a significant difference between faculty members' current positions and their satisfaction with the management practices related to teaching and research: $\mathrm{X}^{2}(4$, $\mathrm{N}=38)=38.0, \mathrm{p}<0.05$ and therefore the hypothesis is accepted.

Hypothesis 5: there is a significant difference between faculty members' current positions and their satisfaction with their universities' policies. The average satisfaction level with university policies for Full professors is ( $\mathrm{S} . \mathrm{D}=0.41$, Mode=dissatisfied, $\mathrm{N}=6$ ), the average satisfaction level for Associate Professors is ( $\mathrm{S} . \mathrm{D} .=0.4$, Mode=dissatisfied, $\mathrm{N}=11$ ), the average satisfaction for Assistant Professors is (S.D. $=0$, Mode $=$ satisfied, $\mathrm{N}=16$ ), the average satisfaction level of Adjunct Faculty members is (S.D. $=0$, Mode $=$ dissatisfied, N=2), and the average satisfaction level of instructors is (S.D. $=0$, Mode $=$ satisfied, N=3). Since the two variables are nominal, the chi-square test was done. The results show that there is a significant difference between faculty members' current positions and their satisfaction with their universities' policies: $\mathrm{X}^{2}(8, \mathrm{~N}=38)=38.85, \mathrm{p}<0.05$ and therefore the hypothesis is accepted.

The most important results in this section are the problems of teaching overload that faculty members are experiencing in the private university, which is more than the workload policy allows for. Faculty members in the public university have a lot of administrative duties that are also affecting their research and publications negatively. This problem of work overload was discussed with deans and faculty members through the interview instrument. Another important result that was found through the survey is that the implementation of some TQM concepts in the public university such as empowerment, self-evaluation, and self-improvement had already occurred. On the other hand, the private university uses a lot of monitoring and evaluation of faculty members, 
which is done by the office of institutional effectiveness for the sake of improvement. Therefore, each university uses the TQM characteristics in different manners, and these are discussed in the next section.

\subsection{In-Depth Semi-Structured Interview}

Faculty members were recruited for the interview through criterion sampling and by meeting the following: 1) have significant publishing records in peer review journals so they are aware of the academic principles and the unique nature of the academic profession that requires time and capability to conduct research, and 2) have at least five years of teaching experience in higher education so they have been teaching long enough to identify what is done in their universities' management systems and how TQM would affect scholarly values. Following the emergent study approach, faculty members who reported in the questionnaire that they had academic working experience in Dubai were also interviewed in order to collect more information about management systems in other universities in Dubai. In addition, there were a few extra interviews with faculty members through snowballing. These people were recommended by interviewees who had been researching quality management, or a faculty member who resigned from one of those universities due to management decisions. Besides describing the management systems in their universities the main role of faculty members as interview subjects was to give their interpretations about the possibility of implementing TQM in higher education in order to help in the model building process. In total 25 faculty members were interviewed, including 19 academics without administrative roles and 6 academics in senior administrative positions in the academic departments.

The interview subjects' selection is summarized in Table 4: In depth semi-structured interviews subjects' selection.

Table 4. In depth semi-structured interviews subjects' selection

\begin{tabular}{lccc}
\hline University & Faculty Members & Senior administrators & Total \\
\hline Public University & 4 & 2 & 6 \\
Private University & 9 & 2 & 11 \\
$\begin{array}{l}\text { Private University (with academic } \\
\text { experience in other universities in Dubai) }\end{array}$ & 6 & 2 & 8 \\
Total & 19 & 6 & 25 \\
\hline
\end{tabular}

The discussion of senior administrators in the private university included many more management concepts and practices. Contrary to this, the results of the interviews done in the public university with top administrators and faculty members show a different management style including peer and self-evaluation.

Through the interview instrument, it can be seen that there is a common problem between the two universities that faculty members are facing, which is a lack of research time. Even faculty members who have experience in other universities in Dubai reported the same problem in their previous universities. For example, faculty members in the private university are suffering from the problem of teaching overload; however faculty members in the public university are facing the problem of administrative tasks and form filling which prevents them from conducting research.

The most important issues that they are concerned about are focusing more on research, reducing the number of students in their classrooms, self-evaluation, self-improvement, peer review, empowerment of faculty, more teamwork, less form filling, less reporting, and less documentation. All of this information along with document analysis, the survey results, and part of the literature review helped in designing the new TQM model for higher education. 


\section{A New TQM Model for Dubai University}

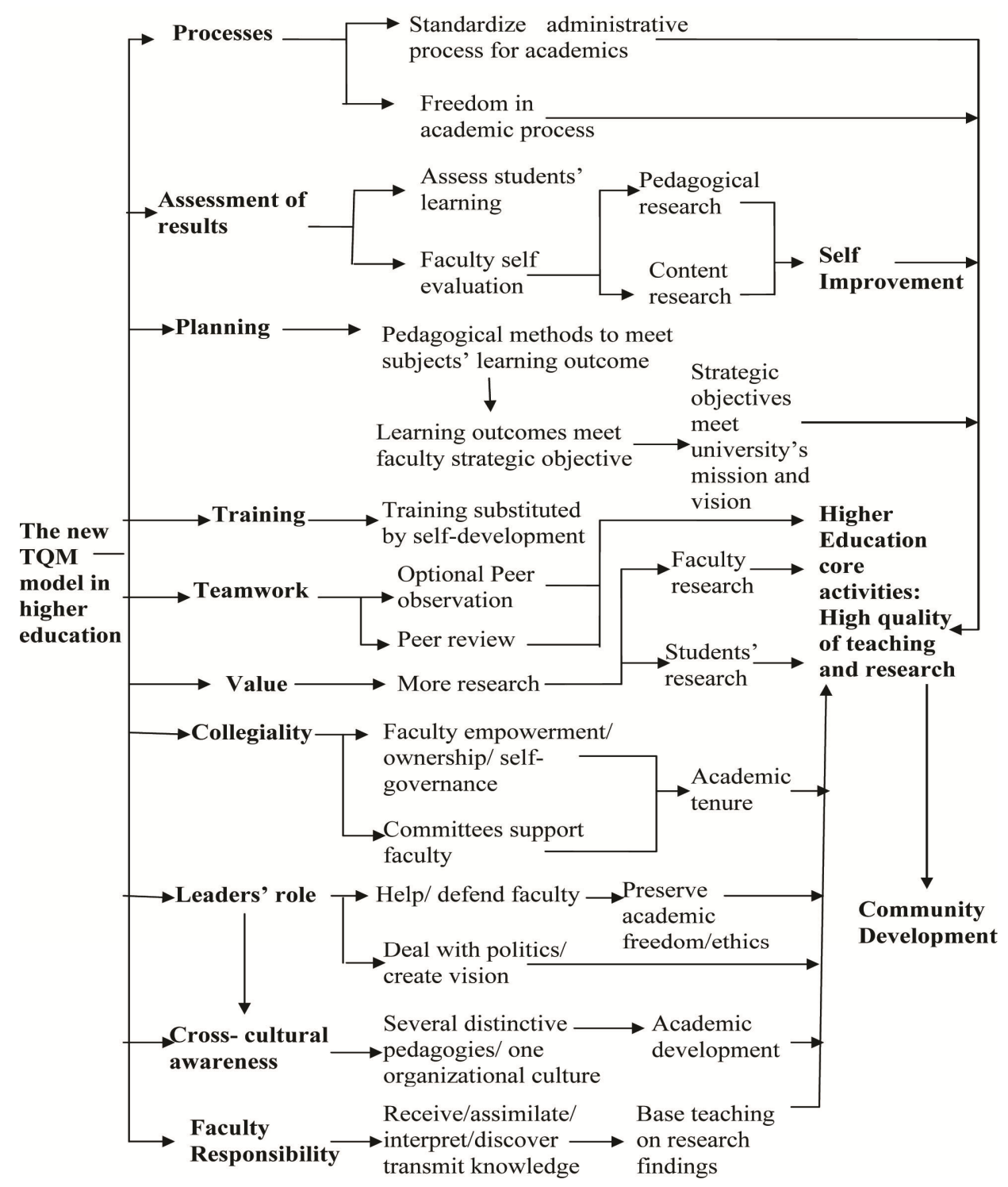

Figure 2. The new management model of higher education in Dubai, UAE

The result of this paper is the New TQM model for Higher Education as presented above in Figure 2.

According to the literature meta-analysis of the defenders and opponents of TQM in higher education, and based on the interpretations and data collected from the empirical study: organizing, documenting, and continuously improving administrative processes in academic departments are positive and helpful for academics. However, the main processes for academics presenting the core activities in higher education of "teaching and research" should be based on professional autonomy. Accordingly, the concept of empowerment and leadership from TQM should be used here since faculty members are professionals who are the most aware of their teaching and research processes. According to the new TQM model they should have the total freedom of designing the syllabi of their courses, teaching tools, assessment methods and marking criteria, and faculty members could plan their pedagogical methods based on the learning outcomes that the faculty set. Those learning outcomes should meet the strategic objectives of the faculty based on the mission and vision of the university. Milakovich (2006) considers that empowering people is essential for a successful TQM, where people who own their processes and form them based on what they believe is true perform at a very high level and benefit the whole organization. 
This new model includes both the rights and responsibilities of faculty members. The occupation of academics is called a profession because it has distinctive privileges, but also special obligations (Shils, 1997, p. 10). The UNESCO international covenant includes the duties and responsibilities of faculty members that are integrated in the new model. Therefore, according to the new model, the responsibility of every faculty member consists of receiving, assimilating, and discovering knowledge, interpreting and transmitting knowledge about methods of discovery, validating knowledge, basing teaching on research findings, ensuring the fair discussion of contrary views, respecting the academic freedom of others in the academic community, ethical and professional standards in scholarship including teaching and research, responding to contemporary society's problems, and preserving the world's historical heritage.

All of the above characteristics of the new model could lead to ultimate results in higher education being presented in a higher quality of teaching and research. TQM requires controlling and measuring results to take corrective action in the case of non-conformance with standards. In higher education faculty members are professionals who know how to check the results of their performance, and this can be done through two assessment methods according to the new model: first by assessing students' learning through methods that the faculty member can decide based on the content and the learning objectives of each subject, and secondly by, the self-evaluation of teaching methods and self-improvement through pedagogical research in one's fields.

Wiklund et al. (2003) criticize TQM for requiring a lot of reporting and too many details, as it takes time to collect statistical data that might not be useful after a short period of time and quantitative assessment is not appropriate for many scholarly and teaching activities. Reporting is also modified in the new model, and it is confined to reporting about student performance based on each university's policies. However, the model does not include any reporting about faculty performance since it is based on self-evaluation for self-improvement by each faculty member individually.

Continuous improvement is based on self-evaluation, and this is a process that faculty members can manage and work on individually every semester based on Deming's PDCA cycle (Deming, 1986). Every faculty member plans for the semester, and at the end of the semester he/she can check whether all learning outcomes are achieved, and based on this improvement plans can be set.

Training is part of TQM but McCulloch (1993) argues that training for faculty should be substituted by self-development. The new model adopts this concept and substitutes training in TQM with self-development through self-evaluation and continuous improvement.

Based on meta-analysis, in TQM customers are always right and their satisfaction is essential. Accordingly, their feedback should always be checked for the sake of continuous improvement. In the literature of TQM in higher education there is a lot of debate about identifying the customers in higher education. According to Antony and Pierce (2002), higher education customers are both students and businesses, and the products are "practice knowledge" and "communication skills". Sirvanci (2004) claims that a secondary student enrolling in higher education should be considered in the same way as raw material that goes through the production process from one step to another until they graduate and become products for employers and compete with one another in the market. On the other hand, Pfeffer and Coote (1991) consider that a student is an "active participant" in education and not a customer or a product. For some scholars the student is the customer, and higher education institutes should attract those customers if they provide a valuable quality of education. To others, customers are employers and students are products presented as graduates, who may or may not attract employers. According to the new model of this paper, higher education is completely different from industry and it can neither consider students as customers nor as products. Accordingly, the customer and the product are the same, which is "community development". When professors, top administrators, and universities work to serve community development the product would be looking for community development as an ultimate result.

The CAA requires administrative tasks besides teaching and research from faculty members, but in some cases universities exploit this standard and require a lot of administrative task and teaching overload in order to reduce the cost of hiring more academic and administrative staff. It could be possible that reducing costs is not bad, but when it adversely impacts research the cost that universities and the society pay would be much higher.

According to Birnbaum (1988), the collegial model is based on trust between all member of higher education including not only faculty members and top administrators but also students and administrative staff. The UNESCO international covenant on academic freedom focuses on professional autonomy and academic freedom in order to guarantee the fulfilment of higher education functions (UNESCO, 2015). The new model integrates the characteristics of the collegial model where the role of deans is to advocate academics and represent their interests within a self-governance organizational structure (Abbott-Chapman, 2005; Crebert, 2000). 
The new model requires academic tenure within its collegial characteristics. Tenure has a major positive impact in shared governance. Carmichael $(1988$, p. 453) argues that "tenure is necessary because without it incumbents would never be willing to hire people who might turn out to be better than themselves". Rosovsky (1990) also links tenure with collegiality by stating that collegiality develops gradually and cannot be created spontaneously or instantly. It needs time to be built, and tenure is one of the major reasons for building collegiality where people belong to one community that they care about.

Teamwork is essential in TQM, and this cannot be achievable in higher education according to Kosh (2003) since committees try to hinder work more than they just work on getting it done. Contrary to this, the new model suggests that teamwork can be used for peer review in two ways, first through peer observation of teaching which is optional, and the results should be confidential between the observer and the observed faculty with one aim of continuous improvement, and secondly through a peer review of research.

In TQM value is based on increasing quality and reducing cost. However, in the new model value is created by enhancing research. It is essential to focus on research in higher education which leads to creating knowledge and community development, not only research done by faculty but also students who should be encouraged to conduct their own research, whether through assessment methods or even through encouraging them to publish in order to investigate, be more involved in inquiry, and to question all that they study and review.

Globalization is impacting the contexts in which universities now constitute their multicultural populations, thus leading to ethnic, religious, cultural, and social diversity. Although the context of the study is Dubai, universities in this Emirate are very diverse and include faculty and students from hundreds of nationalities. Bartlett (2000), and Rayner and Gunter (2005) argue that diversity is not a problem that should be resolved in higher education, and instead it is a resource that brings a lot of value to the university context. According to Alexander (2004), cultural diversity adds many pedagogical values to higher education through several distinctive pedagogies, which contribute to academic professional development for faculty members and leaders.

The role of leaders in the new model consists of empowering faculty members and creating ownership on what they teach and the way they teach. The model also emphasizes the political intelligence of academic leaders to keep politics away from the university as Bezzina, Starratt and Burford (2009) discuss in their research. The model also requires leaders to use politics to get the best for the university such as seeking resources and generating opportunities for faculty members, as discussed by Ramsden (1998). Creating the right vision and working on achieving it regardless of all the challenges that they may face is another essential job of higher education leaders according to the new model. The most important vision is building the community and creating an educated environment beyond the university, and leaders need to have clear objectives to achieve this (Murphy, 2002).

In conclusion, the contribution that this study has made to the literature of quality management in higher education is a new model of TQM that doesn't damage the scholarly values of higher education and enhances professional autonomy, including academic freedom and academic quality in teaching and research. However future research should be done in administrative departments and with students. It is very important to look for a management model that enhances teaching, learning, and research from the perspective of faculty members and students simultaneously.

\section{References}

Abbott-Chapman, J. (2005). Competing discourses in higher education: Giving voice to the public intellectual. ISSA Review, 4(1), 14-21.

Alexander, R. J. (2004). Towards dialogic teaching: Rethinking classroom talk. New York.

Antony, J., \& Preece, D. (2002). Understanding, Managing and Implementing Quality. London: Routledge. https://doi.org/10.4324/9780203464083

Bartlett, M. (2000). Diversity: Missing the opportunity in 21st-century resourcing. London: Bartlett Merton/Kingshill.

Bezzina, M., Starratt, R., \& Burford, C. (2009). Pragmatics, politics and moral purpose: The quest for an authentic national curriculum. Journal of Education, 47(5), 545-556. https://doi.org/10.1108/09578230910981053

Birnbaum, R. (1988). How colleges work: The cybernetics of academic organization and leadership. San Francisco: Jossey-Bass. 
Carmichael, H. L. (1988). Incentives in Academics: Why Is There Tenure? Journal of Political Economy, 96(2), 453-472. https://doi.org/10.1086/261547

Clarke, J. (2004). Dissolving the Public Realm? The logic and Limits of Neo-Liberalism. Journal of Social Policy, 33(1), 27-48. https://doi.org/10.1017/S0047279403007244

Commission for Academic Accreditation (CAA). (2016). Standards for Licensure and Accreditation. Retrieved February 23, 2016, from https://www.caa.ae/caa/images/Standards2011.pdf

Crebert, G. (2000). Links between the purpose and outcomes of planning: Perception of heads of school at Griffiths University. Journal of Higher Education Policy and Management, 22(1), 73-84. https://doi.org/10.1080/713678135

Crosby, P. B. (1979). Quality is Free. New York: McGraw-Hill.

Deem, R. (1998). New managerialism and higher education: The management of performances and cultures in universities in the United Kingdom. International Studies in Sociology of Education, 8(1), 47-70. https://doi.org/10.1080/0962021980020014

Deming, W. E. (1986). Out of the Crisis. Cambridge, MA: The MIT Press.

Deming, W. E. (2000). The new economics (2nd ed.). Cambridge, MA: The MIT Press.

Denzin, N. K., \& Lincoln, Y. S. (2008). Collecting and interpreting qualitative materials. Thousand Oaks, CA: Sage Publications.

Evans, J. R., \& Lindsay, W. M. (2005). The Management and Control of Quality. Ohio: Thomson south-western.

Giamatti, A. B. (1988). A Free and Ordered Space: The Real World of the University. New York: W. W. Norton.

Glesne, C. (2002). Becoming Qualitative Researchers. Boston: Pearson Education.

Heriot, K. C., Franklin, G., \& Austin, W. W. (2009). Applying for Initial AACSB Accreditation: An Exploratory Study to Identify Costs. Journal of Education for Business, 84(5), 283-289. https://doi.org/10.3200/JOEB.84.5.283-289

Hofstede, G. (1991). Cultures and Organizations: Software of the mind. London: McGraw-Hill.

Juran, J. M. (1995). A History of Managing for Quality. Milwaukee, Wisconsin: ASQC Press.

Juran, J. M. (1999). Juran's quality handbook (4th ed.). New York: Mc Graw Hill.

Juran, J. M. (2004). Architect of Quality: The Autobiography of Dr. Joseph M. Juran (1st ed.). New York: McGraw-Hill.

Kosh, J. V. (2003). TQM: Why is its impact in higher education so small? The TQM Magazine, 15(5), 325-333. https://doi.org/10.1108/09544780310487721

McCulloch, M. (1993). Total Quality Management: Its Relevance for Higher Education. Quality Assurance in Education, 1(2), 5-11. https://doi.org/10.1108/09684889310044655

Milakovich, M. E. (2006). Improving Service Quality in the Global Economy. Boca Raton: Auerbach Publications.

Morgan, G. (2006). Images of Organization. California: Sage Publications, Inc.

Murphy, J. (2002). The Educational Leadership Challenge: Redefining Leadership for the 21st Century. Chicago: National Society for the Study of Education.

Pfeffer, N., \& Coote, A. (1991). Is Quality Good For You? A Critical review Quality Assurance in the Welfare Services. London: Institute of Public Policy Research.

Ramsden, P. (1998). Learning to Lead in Higher Education. New York: Routledge Falmer. https://doi.org/10.4324/9780203278116

Rayner, S. (2009). Educational diversity and learning leadership: A proposition, some principles and a model of inclusive leadership? Educational Review, 61(4), 433-447. https://doi.org/10.1080/00131910903404004

Rayner, S., \& Gunter, H. (2005). Rethinking leadership: Perspectives on remodelling practice. Educational Review, 57(2), 151-162. https://doi.org/10.1080/0013191042000308332

Rochford, F. (2003). Academic freedom as insubordination: The legalisation of the academy. Education and the Law, 15(4), 249-262. https://doi.org/10.1080/0953996042000182156 
Rosovsky, H. (1990). The University: An Owner's Manual. New York: W.W. Norton.

Shils, E. (1997). The Calling of Education: The Academic Ethics and Other Essays on Higher Education. Chicago: The University of Chicago Press. https://doi.org/10.7208/chicago/9780226753409.001.0001

Sirvanci, M. B. (2004). Critical issues for TQM implementation in higher education. TQM Magazine, 16(6), 382-386. https://doi.org/10.1108/09544780410563293

Stake, R. E. (1995). The art of case study research. Thousand Oaks, CA: Sage.

Trompenaars, A. (1993). Riding the waves of culture: Understanding cultural diversity in business (2nd ed.). London: Nicholas Brealey Pub.

UNESCO international covenant on academic freedom. (2015). Recommendation concerning the status of Higher-Education Teaching Personal.

Wiklund, H., Klefsjö, B., Wiklund, P. S., \& Edvardsson, B. (2003). Innovation and TQM in Swedish higher education institutions-possibilities and pitfalls. The TQM Magazine, 15(2), 99-107. https://doi.org/10.1108/09544780310461116

Wright, B. E., Manigault, L. J., \& Black, T. R. (2004). Quantitative Research Measurement in Public Administration: An Assessment of Journal Publications. Administration \& Society, 35(6), 747-764. https://doi.org/10.1177/0095399703257266

\section{Copyrights}

Copyright for this article is retained by the author(s), with first publication rights granted to the journal.

This is an open-access article distributed under the terms and conditions of the Creative Commons Attribution license (http://creativecommons.org/licenses/by/4.0/). 